\title{
Screening of Diabetes in Pregnancy
}

\author{
Gebelikte Diabet Taraması
}

\author{
Barış Sever $\odot$, Halil Gürsoy Pala $\odot$
}

Derleme

\section{ABSTRACT}

The prevalence of gestational diabetes mellitus (GDM) is approximately $6 \%$ of pregnant women in the United States. The prevalence ranges is about from $2 \%$ to $38 \%$ worldwide and varies among racial-ethnic groups, often paralleling the prevalence of type 2 diabetes. The prevalence also varies due to differences in screening practices, population characteristics (eg, mean age and body mass index [BMI] of pregnant women), testing method, and diagnostic criteria. The prevalence is increasing over time, possibly due to increases in mean maternal age and weight, particularly with increasing obesity. In 2010, the International Association of Diabetes and Pregnancy Study Groups proposed new screening and diagnostic criteria for diabetes in pregnancy. Using these criteria, the global prevalence of hyperglycemia in pregnancy is estimated at 17\%, with regional estimates ranging from $10 \%$ in North America to 25\% in Southeast Asia. Different screening programs are carried out in different clinics, and all these differences lead to different results in the frequency of GDM. The criteria of the method and threshold value acceptance depends on the health policies of the countries, the experience of the clinicians and the characteristics of the patient population. In this review, we analyzed the methods recommended for GDM screening in pregnancy.

Keywords: Gestational diabetes, diabetes screening tests, oral glucose tolerance test

öz

Geleneksel olarak tanımlandığı gibi gestasyonel diabetes mellitus (GDM) prevalansı Amerika Birleșik Devletleri'ndeki gebe kadınların yaklaşık yüzde 6'sıdır. Prevalans dünya genelinde yaklaşık \%2 ile \%38 arasında değişmektedir ve ırksal-etnik gruplar arasında, genellikle tip 2 diyabet prevalansına paralel olarak değişmektedir. Prevalans ayrıca tarama uygulamaları, popülasyon özellikleri (örneğin, hamile kadınların ortalama yașı ve vücut kitle indeksi [BMI]), test yöntemi ve tanı kriterlerindeki farklııklar nedeniyle de değişir. Prevalans, muhtemelen ortalama anne yaşı ve kilosundaki artışlara, özellikle artan obeziteye bağlı olarak zamanla artmaktadır. 2010 yılında, Uluslararası Diyabet ve Gebelik Çalışma Grupları Birliği (International Association of Diabetes and Pregnancy Study Group), gebelikte diyabet için yeni tarama ve tanı kriterleri önermiştir. Bu kriterler kullanılarak, gebelikte hipergliseminin küresel prevalansının yüzde 17 olduğu tahmin edilmektedir ve bölgesel tahminler Kuzey Amerika'da yüzde 10 ile Güneydoğu Asya'da yüzde 25 arasında değişmekte olduğu yönündedir. Farklı kliniklerde farklı tarama programları yürütülmekte olup, tüm bu farklııklar GDM sıklığında değiş̧ik sonuçların bulunmasına yol açmaktadır. Hangi yöntemin, hangi eşik değerin kabul edileceği ülkelerin izlediği sağlık politikalarına, klinisyenlerin deneyimlerine ve hasta popülasyonunun özelliklerine göre değişmektedir. Bu derlemede gebelikte GDM taraması için önerilen yöntemlerin analizini yaptık.

Received/Geliș: 27.07.2021

Anahtar kelimeler: Gestasyonel diyabet, diyabet tarama testleri, oral glukoz tolerans testi

Barış Sever

Izmir Sağlık Bilimleri

Üniversitesi Tepecik Eğitim ve Araştırma Hastanesi Kadın Hastalıkları ve Doğum Anabilim

Dalı Perinatoloji Bilim Dalı,

İmir - Türkiye

drbarissever@gmail.com

ORCID: 0000-0002-9690-8819

H.G. Pala 0000-0003-1569-4474 izmir Sağlık Bilimleri

Üniversitesi Tepecik Eğitim ve Araştırma Hastanesi Kadın Hastalıkları ve Doğum Anabilim Dalı Perinatoloji Bilim Dalı, izmir, Türkiye

Cite as: Sever B, Pala HG. Screening of diabetes In pregnancy. Tepecik Eğit. ve Araşt. Hast. Dergisi. 2021;31(3):293-300.
(C) Telif hakkı T.C. Sağık Bakanlığı izmir Tepecik Eğit. ve Araşt. Hastanesi. Logos Tıp Yayıncılık tarafindan yayınlanmaktadır. Bu dergide yayınlanan bütün makaleler Creative Commons Atff-GayriTicari 4.0 Uluslararası Lisansı ile lisanslanmıștır.

(c) Copyright Association of Publication of the T.C. Ministry of Health Izmir Tepecik Education and Research Hospital. This journal published by Logos Medical Publishing. Licenced by Creative Commons Attribution-NonCommercial 4.0 International (CC BY) 


\section{INTRODUCTION}

There is an increased state of insulin resistance during pregnancy. This increased insulin resistance occurs due to changes in the release of the related hormones (prolactin, $\mathrm{CRH}$, placental lactogen, progesterone). These and other metabolic changes, usually most pronounced in the last trimester, ensure that the fetus receives plenty of nutrients ${ }^{(1,2)}$. GDM is characterized by the inability of pancreatic beta cells to respond adequately to the increased insulin requirements of pregnancy resulting in varying degrees of hyperglycemia. The risks of multiple serious perinatal complications are increased in women with GDM, including gestational hypertension, preeclampsia, polyhydramnios, Caesarean section, and shoulder dystocia ${ }^{(3)}$.

The prevalence of gestational diabetes mellitus (GDM) is approximately $6 \%$ of pregnant women in the United States ${ }^{(4)}$. The prevalence ranges from about $2 \%$ to $38 \%$ worldwide ${ }^{(5)}$ and varies among racial-ethnic groups, often paralleling the prevalence of type 2 diabetes. The prevalence also varies due to differences in screening practices, population characteristics (eg, mean age and body mass index [BMI] of pregnant women), testing method, and diagnostic criteria. The prevalence increases over time, possibly due to increases in mean maternal age and weight, particularly increasing obesity ${ }^{(6-8)}$. In 2010, the International Association of Diabetes and Pregnancy Study Groups proposed new screening and diagnostic criteria for diabetes in pregnancy (9). Using these criteria, the global prevalence of hyperglycemia in pregnancy is estimated at $17 \%$, with regional estimates ranging from $10 \%$ in North America to $25 \%$ in Southeast Asia ${ }^{(10)}$. In 2017, the American College of Obstetricians and Gynecologists states that the diagnosis of gestational diabetes mellitus usually requires meeting or exceeding two or more glucose thresholds in a 100-gram threehour glucose tolerance test (GTT). However, some clinicians argue that only one high glucose level may be sufficient for diagnosis ${ }^{(11)}$. Importantly, the risks of these outcomes increase as maternal fasting plasma glucose levels rise above $75 \mathrm{mg} / \mathrm{dL}$ (4.2 mmol/L) and the $1^{\text {st }}$ and $2^{\text {nd }}$ hour OGTT values increase. This is a constant effect; there is no clear cutoff that defines patients at high risk of adverse obstetric outcomes (12). As a long-term effect, women with GDM are at risk of developing type 2 diabetes as well as cardiovascular disease. Babies born as a result of this type of pregnancy are considered to be at risk for long-term sequelae such as obesity, abnormal glucose tolerance, hypertension or metabolic syndrome during puberty and beyond. In addition, both gestational and pregestational diabetes mellitus have been associated with an increased risk of autism and other adverse neurodevelopmental outcomes in children ${ }^{(13)}$.

Gestational diabetes can cause many morbidities. These can be listed as follows ${ }^{(14,15)}$ :

- Preeclampsia, gestational hypertension

- Macrosomia

- Polyhydramnios

- Placentomegaly

- Increased cesarean rates

- Increased perinatal mortality

- Neonatal hypertrophic cardiomyopathy

- Increased risk of metabolic problems such as hyperbilirubinemia, hypoglycemia, hypocalcemia in the newborn

\section{Risk factors for gestational diabetes}

Pregnant women with one of the risk factors listed below are more likely to have GDM. The higher number of listed risk factors has the higher probability of developing GDM ${ }^{(16)}$ :

* Personal history of impaired glucose tolerance, $\mathrm{HbA} 1 \mathrm{C} \geq 5.7$, impaired fasting glucose, or gestational diabetes mellitus in a previous pregnancy.

* History of diabetes, especially in first-degree relatives

* $\quad \mathrm{BMI}>30 \mathrm{~kg} / \mathrm{m}^{2}$ or excessive weight gain between 18-24 weeks

* Advanced maternal age ( $>25$ or 30 years).

* Having a previously unexplained perinatal loss or 
having a baby with a malformation

* Glysuria at first prenatal examination

* Having given birth to a baby weighing more than $4000 \mathrm{~g}$

* $\mathrm{HDL}<35 \mathrm{mg} / \mathrm{dL}$, triglyceride $>250 \mathrm{mg} / \mathrm{dL}$

* Presence of conditions that may accompany diabetes (acanthosis nigricans, PCOS, consumption of steroids, hypertension, vascular system disease)

* Multiple pregnancy

In obese women, losing weight before pregnancy can reduce the risk of developing GDM. During pregnancy, a diet and exercise program that prevents excessive weight gain and targets women at high risk for gestational diabetes also appears to be effective (17). In non-pregnant women, regular moderate exercise reduces the risk of developing type 2 diabetes compared to inactivity. It is unclear whether exercise alone or in combination with diet reduces the risk of GDM because meta-analyses of randomized trials have reported conflicting findings. It has been reported that overweight and obese women benefit most ${ }^{(18)}$.

In addition to exercise, a healthy diet and smoking cessation before pregnancy are healthy behaviors that may be associated with a reduced risk of developing gestational diabetes mellitus. Few studies have been conducted on the role of dietary factors in the development of GDM. There is limited evidence that a diet low in red and processed meat, refined grains, and high-fat dairy products that favors fruits, vegetables, whole grains, and fish reduces the risk of developing GDM ${ }^{(19)}$.

\section{GDM Screening}

Similar methods are generally preferred to detect glucose intolerance. The most commonly used one is to take glucose orally. Drinking the water after it is dissolved and then checking the glucose values in the maternal blood is the basis of the method, no complications, side effects or serious negative feedback is received. However, some women find it difficult to tolerate hyperosmolar drinks. With all accurate screening tests designed, there is more people than those who have the disease, this leads to the existence of the possible misdiagnosis. Misdiagnosis of gestational diabetes can lead to increased maternal anxiety, increase in pregnancy interventions, and administration of treatment without a clear benefit to the woman and her child. The cost implications of screening and not screening have been modeled, and screening for type 2 diabetes prevention in populations with high diabetes prevalence appears to be cost-effective, provided that lifestyle interventions are implemented post-pregnancy ${ }^{(20)}$.

The International Association of Diabetes and Pregnancy Study Groups (IADPSG) concluded that the decision to test for undiagnosed pre-existing diabetes at the first prenatal examination should be based on the background frequency of abnormal glucose metabolism in the population and local conditions (8). Both the American Diabetes Association (ADA) (21) and the American College of Obstetricians and Gynecologists (ACOG) ${ }^{(11)}$ recommend screening for gestational diabetes in women who are overweight and/or have additional risk factors. In contrast, 2014 United States Preventive Services Task Force (USPSTF) guidelines concluded that the available evidence is insufficient to assess the balance between the benefits and harms of screening asymptomatic pregnant women for glucose intolerance before 24 weeks of gestation ${ }^{(22)}$.

Some organizations (IADPSG) advocate a diagnosis of ìovertî diabetes in women who meet the criteria for diabetes at the first pre-pregnancy examination. The ADA criteria for the diagnosis of diabetes in non-pregnant adults can be used for the diagnosis of overt diabetes in early pregnancy (Table 1 ). These values were chosen because they are associated with the development of adverse vascular events in non-pregnant individuals, such as retinopathy and coronary artery disease over time. If a patient in early pregnancy (before insulin resistance) meets the standard ADA criteria for diabetes, the disease is presumed to be prior to pregnancy and should 
Tablo 1. American Diabetes Association (ADA) diabetes diagnostic criteria (FBG: fasting blood glucose, OGTT: oral glucose tolerance test).

$\mathrm{HbA} 1 \mathrm{C} \geq \% 6.5$

\begin{tabular}{c}
$\frac{\text { or }}{\mathrm{FBG} \geq 126 \mathrm{mg} / \mathrm{dL}(7.0 \mathrm{mmol} / \mathrm{L}) \text {. Hunger is defined as no calorie intake for at least } 8 \text { hours }}$ \\
\hline or \\
\hline $75 \mathrm{~g} \mathrm{OGTT} \rightarrow 2$-hour plasma glucose $\geq 200 \mathrm{mg} / \mathrm{dL}$ \\
\hline or
\end{tabular}

or

Random plasma glucose $\geq 200 \mathrm{mg} / \mathrm{dL}$ in a patient with symptoms of classic hyperglycemia or hyperglycemic crisis

be treated similarly to women with pregestational diabetes.

\section{What is the purpose of scanning?}

The purpose of screening is to identify asymptomatic individuals who are most likely to have or develop a particular disease. Screening can be performed as a two-step process where step one identifies people at high risk for the disease, so that step two, the diagnostic test, which is often more complex or costly than the screening test, can be limited to these individuals and not required for low-risk individuals (6). Alternatively, a diagnostic test can be administered to all individuals, which is a one-step process. The two-step approach is the most widely used approach to screen pregnant women with gestational diabetes mellitus in the United States. As the first step, at any time of the day, without requiring fasting, a 50 gram one hour glucose challenge test is applied (glucose challenge test-GCT). Screen-positive patients move on to stage two, the 100 grams, three-hour oral glucose tolerance test (GTT), the diagnostic test for gestational diabetes mellitus. The one-step approach bypasses the screening test and simplifies diagnostic testing by performing only a 75 grams, two-hour oral GTT. In this test, 8 hours of fasting is required.

Thereisnoconsensusamongnationalandinternational organizations on the use of a one-step and two-step approach. Although there are no proven benefits of screening for diabetes in early pregnancy, if the pregnant woman is suspected of having undiagnosed type 2 diabetes, testing can be done at the first prepregnancy examination ${ }^{(9)}$. In particular, women with a previous history of gestational diabetes mellitus have a 48 percent risk of recurrence ${ }^{(23)}$. Although there are no valid criteria for selecting high-risk pregnant women for early screening, as noted above, the American Diabetes Association (ADA) and the American College of Obstetricians and Gynecologists (ACOG) have established risk assessment criteria for estimating diabetes risk (24). Universal screening is done at 24 to 28 weeks of gestation if no early testing has been done or if the early test is negative.

50 grams one hour glucose screening: Regardless of the time elapsed after the last meal, 50 grams of oral glucose is given and plasma glucose is measured one hour later. The following thresholds have been suggested to define a positive scan: $\geq 130 \mathrm{mg} / \mathrm{dL}$, $\geq 135 \mathrm{mg} / \mathrm{dL}$, or $\geq 140 \mathrm{mg} / \mathrm{dL}$. As the threshold value is lowered, the sensitivity increases, but the false positivity increases and therefore the number of OGTT is increased. Glucose loading of 100 grams, which will be applied when the threshold value is exceeded, can be safely performed in women with GDM or undiagnosed type 2 diabetes, as it will not lead to diabetic ketoacidosis. It has been applied to thousands of patients without any serious side effects reported. 
HbA1C: There is not enough data available for its use as a screening test. There is no consensus on which threshold value is acceptable.

Fasting glucose level: It should be noted that GCT may have different threshold values in different populations. In low-resource conditions where universal screening with GCT or diagnostic testing with oral GTT is not possible, using fasting plasma glucose at 24 to 28 weeks to screen women may be a cost-effective approach.

Glucosuria: A positive urine test for glycosuria is not very predictive for GDM, and also a negative urine test for glycosuria is not very predictive of the absence of GDM ${ }^{(25)}$. Glucosuria with normal blood glucose levels is common in pregnant women as it is associated with reduced fractional reabsorption of glucose during pregnancy, resulting in higher urinary excretion rates.

\section{GDM diagnostic tests}

Diagnostic tests include oral glucose tolerance tests (OGTT). GTT can be performed as a 75 grams two hour test or a 100 grams three hour test; there is no consensus on optimum thresholds for a positive test (Table 2). The 100-gram three-hour GTT is typically performed as the second step of the two-step approach, while the 75-gram two-hour test can be performed as a single test in the one-step approach. A single-stage 75 grams two-hour GTT is performed without pre-qualification. Gestational diabetes mellitus is diagnosed when one glucose level rises.
The first step of the two-step approach is a 50 grams one hour glucose challenge test regardless of time of day/previous meals. Screen-positive patients progress to stage two, a 100-gram three-hour GTT, which usually requires two or more elevations of glucose to be diagnosed with gestational diabetes.

Checking the fasting glucose level before applying the OGTT may also be one of the methods that can be used to diagnose GDM. If 75 grams of two-hour OGTT is planned and fasting blood glucose level is $\geq 92 \mathrm{mg}$ / $\mathrm{dL}, \mathrm{GDM}$ is diagnosed and GTT is canceled. If a 100 grams three-hour GTT is planned, no data support a specific fasting limit for the diagnosis of gestational diabetes mellitus, and an abnormal fasting glucose level alone is not diagnostic of gestational diabetes. However, a glucose level of $126 \mathrm{mg} / \mathrm{dL}$ is a reasonable threshold to cancel GTT since diabetes is diagnosed in the general population. This approach requires asking the patient to draw blood for fasting glucose level and then waiting for results before switching to GTT on the same day (post-fasting) or another day (post-fasting), which is tedious.

100 grams OGTT: It is done in 3 hours and when 2 glucose values rise, gestational diabetes mellitus is diagnosed. The most commonly used cut-off values to define high values were suggested by Carpenter and Couctan (Table 2) (26). Carpenter and Coustan values are based on more recent enzymatic testing on plasma samples and reflect current laboratory practice. However, a review of 25 studies noted that women with 2 abnormal values in the three-hour 100 grams oral GTT generally had an increased risk for

Tablo 2. Range of diagnostic criteria for gestational diabetes mellitus (CDA: Canadian Diabetes Association; WHO: World Health Organization; IADPSG: International Association of Diabetes and Pregnancy Study Groups; GTT: glucose tolerance test).

\begin{tabular}{lccccc}
\hline & & Fasting (mg/dL) & $\mathbf{1}^{\text {st }}$ hour $(\mathbf{m g} / \mathbf{d L})$ & $\mathbf{2}^{\text {nd }}$ hour $(\mathbf{m g} / \mathbf{d L})$ & $\mathbf{3}^{\text {rd }}$ hour $(\mathbf{m g} / \mathbf{d L})$ \\
\hline $\begin{array}{l}\text { Two steps } \\
(100 \text { gr glucose })\end{array}$ & Carpenter and Coustan & 95 & 180 & 155 & 140 \\
\hline $\begin{array}{l}\text { Two steps } \\
(75 \text { gr glucose })\end{array}$ & CDA & 95 & 191 & 160 \\
\hline $\begin{array}{l}\text { One step } \\
(75 \text { gr glucose })\end{array}$ & WHO & $92-125$ & 180 & 153 \\
\cline { 2 - 6 } & IADPS & $92-125$ & 180 & 153 \\
\hline
\end{tabular}


worse outcomes than women with 1 abnormal value (27). Citing this systematic review, the 2017 ACOG practice bulletin said that a diagnosis of gestational diabetes mellitus often requires meeting or exceeding two or more glucose thresholds. However, the ACOG noted that some clinicians may choose to make the diagnosis based on an elevated glucose value ${ }^{(11)}$. It is unclear whether such patients will benefit from treatment.

75 grams two-hour OGTT: Gestational diabetes mellitus is diagnosed when one glucose level rises. The most commonly used thresholds to define high values were suggested by the IADPSG (Table 2). The 75 grams two-hour oral GTT is more convenient, better tolerated, and more sensitive to identify pregnancy at risk of adverse outcomes (eg, gestational hypertension, preeclampsia, macrosomia) than the 100-gram three-hour oral GTT, but requires the patient to fast for 8 hours ${ }^{(28)}$. The thresholds defined by the IADPSG for 75 grams of two-hour oral GTT are essentially those established based on the HAPO study. These thresholds represent glucose values at which infant birth weight, cord C-peptide (indicator for fetal insulin level), and newborn body fat percentage $>90^{\text {th }}$ percentile are 1.75 times the estimated probabilities of these outcomes at mean glucose levels. Compared with women in the HAPO study with all glucose values below the threshold, women who exceeded one or more of these thresholds had a twice as high incidence of preeclampsia. There was a $45 \%$ increase in preterm birth and primary cesarean delivery. If the patient cannot tolerate the OGTT, the ëserial glucose monitoringí method may be useful for follow-up. Periodic fasting and one or two hour postprandial blood glucose tests are a monitoring option for women at high risk for gestational diabetes mellitus who cannot tolerate oral glucose testing. Periodic testing should be done at week 24 to 28 (when GCT will be performed) and week 32 (peak insulin resistance). Obtaining periodic fasting glucose and $\mathrm{HbA} 1 \mathrm{C}$ are similar options.

Retest: In most protocols, a negative GTT at weeks 24 to 28 is not repeated later in pregnancy. However, several studies have shown that repeat testing after an initially normal GTT will identify additional cases in 4 to 29 percent of cases, depending on the timing and indication for retesting ${ }^{(29)}$. Recurrent GTT may be considered on an individualized basis in women with sonographic findings suggestive of a diagnosis of gestational diabetes, such as fetal overgrowth or polyhydramnios, or in women with a past history of gestational diabetes. Women with an abnormal value in the GTT who were not initially diagnosed with gestational diabetes may also be diagnosed with the disorder if they have these sonographic findings.

\section{Clinical approaches to screening}

a) Initial examination: There are clinics that perform universal screening for overt diabetes by checking $\mathrm{HbA1C}$ in all patients at the first prenatal visit [25]. Overt diabetes is diagnosed when $\mathrm{HbA} 1 \mathrm{C} \geq 6.5$ (Table 1). Given the increasing incidence of type 2 diabetes, it is reasonable to consider that early testing is both desirable and appropriate when routine first prenatal laboratory tests are performed, and that diagnosing these patients with appropriate treatment may improve pregnancy outcomes. HbA1C is not an appropriate test to detect mildly impaired glucose tolerance. In early pregnancy, the American Diabetes Association (ADA) criteria are used for the diagnosis of overt diabetes (Table 1). Neither the ACOG studies nor the IADPSG/ADA studies provided sufficient evidence for the use of diabetes diagnostic tests in the first or early second trimester.

b) 24-28 weeks: For women who have not previously been diagnosed with diabetes, a two-stage testing approach may be preferred at 24 to 28 weeks of gestation, following ACOG guidelines (50 grams of oral glucose) (100 grams OGTT for those with a positive 50 grams challenge test) ${ }^{(11)}$. While the single-stage 75-gram two-hour oral GTT using IADPSG criteria is more sensitive than the twostage approach to identify pregnant women with abnormal GTT, this clearly has not been shown to have an impact on improving perinatal outcomes. While screening with the 50 grams glucose test has 
the practical advantage that it can be performed at any time of the day without dietary preparation, the one-step approach requires all patients to fast overnight before laboratory tests and be performed in the morning. Since the incidence of diabetes is more common in the American population, $135 \mathrm{mg} / \mathrm{dL}$ is generally accepted as the positive threshold value of the 50 grams test in the United States.

\section{CONCLUSION}

Gestational diabetes has been seen with increasing frequency in recent years. Increasing consumption of fast-food, increasing sedentary life and advanced age pregnancies seem to be responsible for all this increased risk. With a good glucose regulation, it is possible to limit the possible bad fetal-maternal consequences of gestational pregnancy. High glucose levels, especially with long-term exposure, increases the risk of fetal complications. With gestational diabetes screening, risky pregnancies can be identified in the early period and the possibility of intervention can be obtained. Although there are different screening methods and different glucose threshold values all over the world, it is important for each clinic to evaluate the pregnant woman in terms of gestational diabetes.

Conflict of Interest: The authors report no conflicts of interest. The authors alone are responsible for the content and writing of this article.

Funding: None.

\section{REFERENCES}

1. Pala HG, Ozalp Y, Yener AS, Gerceklioglu G, Uysal S, Onvural A. Adiponectin Levels in Gestational Diabetes Mellitus and in Pregnant Women Without Glucose Intolerance. Adv Clin Exp Med 2015, 24, 1, 85ñ92. [CrossRef]

2. Pala HG, Ozalp Y, Gerceklioglu GS, Yener AS, Uysal S, Onvural A. Gestasyonel Diabetes Mellitus ve Normal Glukoz Toleransına Sahip Gebelerde İnsülin Direnci, Laboratuvar Bulguları ve Klinik Faktörlerin Karşılaştırılması. Turkiye Klinikleri J Gynecol Obst 2013;23(3):141-7.

3. Johns EC, Denison FC, Norman JE, Reynolds MR. Gestational diabetes mellitus: mechanisms, treatment and complications. Trends Endocrinol. Metab. 2018;29(11):743-754. [CrossRef]

4. Deputy NP, Kim SY, Conrey EJ, Bullard KM. Prevalence and
Changes in Preexisting Diabetes and Gestational Diabetes Among Women Who Had a Live Birth - United States, 2012-2016. MMWR Morb Mortal Wkly Rep 2018; 67:1201. [CrossRef]

5. Bilous RW, Jacklin PB, Maresh MJ, Sacks DA. Resolving the Gestational Diabetes Diagnosis Conundrum: The Need for a Randomized Controlled Trial of Treatment. Diabetes Care 2021; 44:858. [CrossRef]

6. Carol L, Gestational Diabetes. In: Terry DF, editor. A CaseBased Guide to Clinical Endocrinology. 2nd ed. USA: Springer; 2015. p.333-39. [CrossRef]

7. Kim SY, Saraiva C, Curtis M, et al. Fraction of gestational diabetes mellitus attributable to overweight and obesity by race/ethnicity, California, 2007-2009. Am J Public Health 2013; 103:e65. [CrossRef]

8. Feig DS, Hwee J, Shah BR, et al. Trends in incidence of diabetes in pregnancy and serious perinatal outcomes: a large, population-based study in Ontario, Canada, 19962010. Diabetes Care 2014; 37:1590. [CrossRef]

9. International Association of Diabetes and Pregnancy Study Groups Consensus Panel, Metzger BE, Gabbe SG, et al. International association of diabetes and pregnancy study groups recommendations on the diagnosis and classification of hyperglycemia in pregnancy. Diabetes Care 2010; 33:676. [CrossRef]

10. Guariguata L, Linnenkamp U, Beagley J, et al. Global estimates of the prevalence of hyperglycaemia in pregnancy. Diabetes Res Clin Pract 2014; 103:176. [CrossRef]

11. ACOG Practice Bulletin No. 190: Gestational Diabetes Mellitus. Obstet Gynecol 2018; 131:e49. [CrossRef]

12. Farrar D, Simmonds $M$, Bryant $M$, et al. Hyperglycaemia and risk of adverse perinatal outcomes: systematic review and meta-analysis. BMJ 2016; 354:i4694. [CrossRef]

13. Lowe WL Jr, Scholtens DM, Kuang A, et al. Hyperglycemia and Adverse Pregnancy Outcome Follow-up Study (HAPO FUS): Maternal Gestational Diabetes Mellitus and Childhood Glucose Metabolism. Diabetes Care 2019; 42:372. [CrossRef]

14. HAPO Study Cooperative Research Group, Metzger BE, Lowe LP, et al. Hyperglycemia and adverse pregnancy outcomes. N Engl J Med 2008; 358:1991. [CrossRef]

15. Pala HG, Ulkumen BA, Koyuncu FM, Baytur YB. Threedimensional ultrasonographic placental volume in gestational diabetes mellitus. J Matern Fetal Neonatal Med, Early Online: 1ñ5, 2015. [CrossRef]

16. Kiani F, Naz MS, et al. The Risk Factors of Gestational Diabetes Mellitus: A. Int J Womens Health 2017; 5:253. [CrossRef]

17. Guo $X Y$, Shu J, Fu XH, et al. Improving the effectiveness of lifestyle interventions for gestational diabetes prevention: a meta-analysis and meta-regression. BJOG 2019; 126:311. [CrossRef]

18. Yu Y, Xie R, Shen C, Shu L. Effect of exercise during pregnancy to prevent gestational diabetes mellitus: a systematic review and meta-analysis. J Matern Fetal Neonatal Med 2018; 31:1632. [CrossRef]

19. Schoenaker DA, Mishra GD, Callaway LK, Soedamah-Muthu SS. The Role of Energy, Nutrients, Foods, and Dietary Patterns in the Development of Gestational Diabetes Mellitus: A Systematic Review of Observational Studies. Diabetes Care 2016; 39:16. [CrossRef]

20. Lohse N, Marseille E, Kahn JG. Development of a model to assess the cost-effectiveness of gestational diabetes mellitus screening and lifestyle change for the prevention of type 2 diabetes mellitus. Int J Gynaecol Obstet 2011; 115 Suppl 
1:S20. [CrossRef]

21. American Diabetes Association. 2. Classification and Diagnosis of Diabetes: Standards of Medical Care in Diabetesó2021. Diabetes Care 2021; 44:S15. [CrossRef]

22. Moyer VA, U.S. Preventive Services Task Force. Screening for gestational diabetes mellitus: U.S. Preventive Services Task Force recommendation statement. Ann Intern Med 2014; 160:414. [CrossRef]

23. Schwartz N, Nachum Z, Green MS. The prevalence of gestational diabetes mellitus recurrence--effect of ethnicity and parity: a metaanalysis. Am J Obstet Gynecol 2015; 213:310. [CrossRef]

24. https://www.uptodate.com/contents/diabetes-mellitus-inpregnancy-screening-and-diagnosis?search=gestational\%20 diabetes\&source=search_result\&selectedTitle=3 150\&usag e_type $=$ default \&display_rank $=3$

25. Buhling KJ, Elze L, Henrich $\mathrm{W}$, et al. The usefulness of glycosuria and the influence of maternal blood pressure in screening for gestational diabetes. Eur J Obstet Gynecol
Reprod Biol 2004; 113:145. [CrossRef]

26. Carpenter MW, Coustan DR. Criteria for screening tests for gestational diabetes. Am J Obstet Gynecol 1982; 144:768. [CrossRef]

27. Roeckner JT, Sanchez-Ramos L, Jijon-Knupp R, Kaunitz AM. Single abnormal value on 3-hour oral glucose tolerance test during pregnancy is associated with adverse maternal and neonatal outcomes: a systematic review and metaanalysis. Am J Obstet Gynecol 2016; 215:287. [CrossRef]

28. Caissutti C, Khalifeh A, Saccone G, Berghella V. Are women positive for the One Step but negative for the Two Step screening tests for gestational diabetes at higher risk for adverse outcomes? Acta Obstet Gynecol Scand 2018; 97:122. [CrossRef]

29. de Wit L, Bos DM, van Rossum AP, et al. Repeated oral glucose tolerance tests in women at risk for gestational diabetes mellitus. Eur J Obstet Gynecol Reprod Biol 2019; 242:79. [CrossRef] 